Saudi Journal of Humanities and Social Sciences

Abbreviated Key Title: Saudi J Humanities Soc Sci

ISSN 2415-6256 (Print) | ISSN 2415-6248 (Online)

Scholars Middle East Publishers, Dubai, United Arab Emirates

Journal homepage: https://saudijournals.com/sjhss

Original Research Article

\title{
Project Advocacy Strategy and Resilience of Widows in Rarieda Sub- County, Siaya County, Kenya
}

Obiero Grace Akinyi*, Abuya Isaac Odhiambo

Department of Open Learning Programmes, University of Nairobi, University Way, Nairobi, Kenya

DOI: $10.36348 /$ sjhss.2020.v05i02.004

| Received: 16.02.2020 | Accepted: 24.02.2020 | Published: 27.02.2020

*Corresponding author: Obiero Grace Akinyi

\section{Abstract}

Widows in developing countries are amongst the most vulnerable and at-risk; and they go through a lot of challenges ranging from cultural issues, socio- economic, and psychological difficulties which exacerbate their vulnerability and risks. A number are disinherited, forced into sex and marriage. For such widows to survive and overcome such challenges, they have to be resilient and rise above the challenges, risks and vulnerabilities. Available evidence suggests that targeted project advocacy may not only empower vulnerable and at risk individuals but may also make them resilient. Few studies have established these relationships. The objective of this study was to determine the influence of project advocacy strategy on resilience of widows in Rarieda Sub-County in Kenya. The design of the study was crosssectional. The target population was 290 composed of project advocacy officers, social services officers, women group leaders and group members. A sample size of 165 was computed using Krejcie Morgan table of estimation. Simple stratified random sampling was used. Data was collected using a questionnaire. Descriptive and inferential data were analysed using SPSS computer package. Descriptive statistics included frequencies, means and standard deviations while inferential statistics included correlation and regression analyses. There was strong correlation between project advocacy strategy and resilience of windows. It is recommended that targeted advocacy strategies should be structured and integrated in community projects supporting widows.

Keywords: Widows, socio- economic, disinherited.

Copyright @ 2020: This is an open-access article distributed under the terms of the Creative Commons Attribution license which permits unrestricted use, distribution, and reproduction in any medium for non-commercial use (NonCommercial, or CC-BY-NC) provided the original author and source are credited.

\section{INTRODUCTION}

Resilience is ability to recover from difficulties, toughness, therefore, the ability of a substance or object to spring back into form. One of the difficulties that lead women to achieve resilience is widowhood which is a state of losing a spouse. In a presentation to the UN on 23rd June, 2011, the President of Institute for Women's Policy Research, Hartmann [1] giving attention to policy structures that touch on women focusing on economic engagement, change, democratic issues and societal security works, property, along with welfare and income, in association with the women's studies and public agendas, at George Washington University, recognized that widowhood is primarily a problem of women. By that time, there were 245 million widows across the World, the report recorded some of the causes of widowhood as; conflicts, massacre and extremism, sickness (especially HIV/AIDS, TB and Malaria), accidents, immature girls in marriage being left early in life by husbands who die of old age, suicide and domestic violence.
Widows are deprived universally [1]. Hindrances are worse in some regions where widowhood can be permanent and widows are marginalized. In such a state, the women then require resilience. Resilience was firstly made known by Holling in 1973 as a model to assist to comprehend the ability of environment with substitute attractors to remain in its original form after disturbance. That resilience is "the capacity of a system to absorb disturbance and reorganize while undergoing change so as to still retain essentially the same functions, structure, identity and feedbacks. Folke, Carpenter, Walker, Scheffer, Chapin and Rockström [2] state that societal- environmental resilience is about people and nature as symbiotic structures. According to Parker, Jimieson, Walsh and Loakes [3] resilience is the psychological ability to acclimate and survive in hardship. Therefore, resilience helps widows in keeping focus and gaining strength to move on with life. 
Project empowerment strategies are embraced to help widows be resilient. A major one being education, summed up as Empowerment and improvement of public safety nets. Project Empowerment strategies then become key in influencing resilience of widows. Project empowerment strategies are those planned activities meant to achieve goals. Dwivedi [4] defines empowerment as a process which enriches people's deep-down effort inspiration by inducing effect, capability, relevance and optimism. Empowered individuals trust their ability to proficiency and respect, impact and opportunity to use their talents.

Powerlessness gives rise to low self-efficacy. It is a process of identifying and removing conditions which cause powerlessness while increasing feelings of self-efficacy. He specifies four basic principles of becoming empowered which are identical with concept of empowerment as liberty, self-determination, selfrestraint and relativity. Paulo Freire, a Brazilian scholar spoke of conscientization, or critical consciousness, in 1968. He defined it as the process through which someone oppressed becomes aware of his situation and is therefore able to take action to change it Kalso [5]. The basic principles of empowerment are closely related to resilience, which have determination, independence, motivation, adaptability and innovation as its key components. Resilience can be said to be the "capacity of a system to survive, adapt, and grow in the face of change and uncertainty" Kaplan [6]. The study delves into project empowerment strategies and how each influences resilience of widows in Rarieda SubCounty. The project empowerment strategies are advocacy, Participation, Training and mentorship.

Advocacy is the dynamic sustenance of an idea or cause articulated through approaches then methods that inspiring the ideas and judgments of individuals Chopra, Ekaeob, Nesbitt, Moussie and Sherpa [7] share about programs aimed at challenging women's uneven responsibility for care labor besides stimulating legislators to appreciate the significance of providing services to back them. Brahic, Olaiya, Jacobs and English [8] explore the commonly underestimated inquiries of casual women laborers and work establishment in the East African export market gardening farms. Sherif [9] argues that "while gender disparity in third World countries is widely studied, the obstacles facing women and the efficacy of the various strategies to overcome it are less well understood". Existing policies for humanizing women's situations depend on multinational advocacy mainly through standards structure.

McGovern [10] states that fresh progress context desires to fuse extensive period anticipation for political and economic sustainability through transnational scarcity suppression objectives. Essential to the program is the advancement and safeguarding of the social privileges of women and girls. The suggested outline defined in the High Level Panel of Eminent Persons' (HLPEP) Report related to women may possibly promote, structure this difficulty however much it advances on the MDGs through growing goals associated with women. "Success will require support for a potent mix of advocacy, movement building and a complex set of ground-based strategies that shift cultural practices, laws and policies that harm women and girls" McGovern [11].

Resilience was first made known by Holling in 1973 as a model to help comprehend the ability of ecosystems with substitute attractors to persevere in the original state subject to distress. That resilience is "the capacity of a system to absorb disturbance and reorganize while undergoing change so as to still retain essentially the same functions, structure, identity and feedback. Folke [12], state that social- ecological resilience is about individuals and environment as codependent systems. Black women living with HIV (BWLWH) exemplify the leading proportion of women with HIV in the U.S. and go through poorer health consequences compared to other women living with $\mathrm{HIV}$, to some extent, due to traumatic experiences, discrimination, HIV-stigma, and stress they face as women. Nonetheless, their individual levels of resilience in the aspect of various difficulties and perceptions of societal stakeholders may enlighten our ground in what way to best enable this populace to endeavor in spite of hardships. According to Parker et al., [13] "resilience is the psychological capacity to adapt and cope with adversity".

\section{REVIEW OF LITERATURE \\ The Concept of Project Empowerment Strategies}

Bringing to fore the model of empowerment to 'community psychology', Rappaport [14] gave this guidance "when most people agree with you, worry. We are worried not because people agree with us, rather because empowerment has perhaps become so widespread that is essentially hard to sidestep". Project empowerment strategies are those planned activities meant to achieve goals. Dwivedi [4], defines empowerment as a procedure which augments people's core effort impetus by prompting effect, capability, significance and excellence.

Empowered individuals trust their ability to proficiency and respect, impact and opportunity to use their talents. Powerlessness gives rise to low selfefficacy. Therefore, is a process of identifying and removing conditions which cause powerlessness while increasing feelings of self -efficacy. He specifies four basic principles of becoming empowered which are identical with the concept of empowerment as liberty, self-determination, self-restraint and relativity. Paulo Freire, a Brazilian scholar spoke of conscientization, or critical consciousness, in 1968. He defined it as the process through which someone oppressed becomes aware of his situation and is therefore able to take 
action to change it Kalso [5]. The basic principles of empowerment are closely related to resilience, which have determination, independence, motivation, adoptability and innovation as its key components. Resilience can be said to be the ability of a structure to endure, adjust, and develop in the face of alteration and improbability [15].

\section{Project Advocacy Strategy}

Advocacy is the dynamic sustenance of an idea or cause articulated through approaches then methods that inspiring the ideas and judgments of individual. Chopra et al., [7] share about programs aimed at challenging women's uneven responsibility for care labor besides stimulating legislators to appreciate the significance of providing services to back them. Focus is tuned to the distinction between critical engagement and constructive engagement and some of the challenges facing the implementers of the work, the implications and lessons that can be learnt. Brahic et al., [8] explore the commonly underestimated inquiries of casual women laborers and work establishment in the East African export market gardening farms, reveals that by placing emphasis on the prerequisites of women workforces, feminist work agitation has encouraged different arrangements of work organizations highlighting achievements, obstacles and impediments.

According to Cherif [9], existing approaches for humanizing women's situations depend on international advocacy mainly by customs development, he nonetheless agrees that efficiency of such methods has mainly escaped methodical assessment. Investigating discrimination in domestic and national acts, which illustrate women's imbalanced nationality, he offers complimentary viewpoint that stresses the part of primary rights-improving women's training points and labor force involvement to describe women's standing. Applying cross- national facts he investigates the impact of culture and elements that progress nationality privileges. He finds out that religious views impacts inheritance and nationality privileges, and that encouraging women's basic rights in training and employment involvement could balance the influence of cultural beliefs.

McGovern [10] argues that fresh progress context desires to fuse extensive period anticipation for political and economic sustainability through transnational scarcity suppression objectives. Essential to the program is the advancement and safeguarding of the social privileges of women and girls. According to McGovern [10], domestic instruments, supporters and transnational development agencies mostly do not entirely handle the problems or challenge the associated multifaceted problems combining religion, socioeconomic levels, societal, traditional and household life. The suggested out line defined in the High-Level Panel of Eminent persons Report, could additionally organize the problem by improving on the
Millennium Development Goals by increasing objectives associated with women. He states that attainment would involve backing for an effective combination of advocacy, drive development and a multifaceted set of ground -based approaches that change traditional activities, acts and rules that harm women. Analysis of women's constitutional rights labor, infrastructure and supporter funding in 3rd world countries show the necessity for attention and long term venture in active labor.

Comeau and Church [10], in an institutional perspective contend that women's advocacy groups handle related problems and have comparable dictates across nations, yet vary significantly in their development and approach adoptions hence seeking to appreciate the magnitude to which established setting compels group approaches to improve knowledge of which aspects inspire advocacy establishments.

\section{Resilience of Widows}

The model of resilience was to a great extent utilized in physical science in accordance with 'idea of capacity to extend' where it is characterized by the 'quality of material to recover its unique structure subsequent to being bowed, compacted, or extended, and building particularly in material sciences and development to determine the limit of a substance or system to keep up and reestablish itself, especially in the presence of stressors' Smynthyna [17]. The Canadian biologist Holling introduced resilience with the investigations of environmental frameworks in the mid-1970s. a decade later, in light of his field of studies and long term perception of contemporary terrestrial biological systems, he refreshed the meaning of resilience to be "ability of a system to maintain its structure and patterns of behavior in the face of disturbance [18]."

According to Howell, Thurston, Schwartz, Jamison and Hasselle [19], adversity is always skewed toward assessing problematic functioning yet many women display resilience following traumatic experiences. Exploring individual, social, network, and social cultural factors can give new knowledge about defensive components related with resilience in ladies presented to intimate partner violence (IPV). Controlling for socio-economic conditions of violence, this article assesses indicators of resilience, which include spiritual factors, social help, network and community attachment, and personal identity [20].

Hirani et al., [21] undertook to examine the usefulness of a 'social support intervention' for improving resilience and personal satisfaction among ladies living in low socio economic parts of Karachi, Pakistan. Results indicate that 'community based social help interventions are gender based orientations, socially fitting, and response saving way to promote resilience of women and to improve their emotional 
well-being. Kaplan et al., [15] point out that an important element of resilience could be 'perilous, unfriendly and undermining life conditions that outcome in individual vulnerability. That an individual resilience is determined by the proportion between the presence of defensive elements and the presence of dangerous conditions [15].

Polk [22] has broken down four patterns of resilience from the individual resilience as; Dispositional pattern, Relational pattern, Situational pattern and Philosophy pattern. Black women living with HIV (BWLWH) exemplify the leading proportion of women with HIV in the U.S. and go through poorer health consequences compared to other women living with HIV, to some extent, due to traumatic experiences, discrimination, HIV-stigma, and stress they face as women. Nonetheless, their individual levels of resilience in the aspect of various difficulties and perceptions of societal stakeholders may enlighten our ground in what way to best enable this populace to endeavor in spite of hardships. Promoting resilience among BWLWH involves an appreciation of utmost adaptive approaches applied to spring back following or in the face of difficulties. 'Both BWLWH and communal interested parties appreciate societal assistance from their community as an imperative resilience resource. Determinations need to be directed at reinforcing both BWLWH and their village in order to encourage resilience and decrease health differences [23].

Table-1: Target Population

\begin{tabular}{|c|c|c|}
\hline Target groups & Population & Sample \\
\hline Women group leaders & 20 & 19 \\
\hline Widows from only widows group & 70 & 63 \\
\hline Registered Group Members & 190 & 73 \\
\hline MGSS Officers & 10 & 10 \\
\hline TOTAL & 290 & 165 \\
\hline \multicolumn{3}{|c|}{ Source: Krejcie and Morgan Table } \\
\hline
\end{tabular}

\section{Sampling Procedure}

Stratified simple random sampling, stratified sampling and purposive techniques were adopted in this study. This sampling procedure makes it possible to sample homogeneous population from the target population. This technique was convenient in this study since it ensured the availability of significant subgroups within the sample. The researcher can representatively sample the least and highly unreachable smaller group in the population, it allows for sampling the rare extremes of the given population. Purposive sampling procedure was also adopted for this study. Strength of purposive sampling procedure lay in picking information rich, in this particular study, the widows for detailed investigation associated with vital concerns being surveyed that were, project empowerment strategies and resilience of widows. Purposive sampling can be applied in quantitative and qualitative surveys and suitable for homogeneity of the sample in this case, the widows due to the information needed [25].

\section{RESEARCH METHODOLOGY Research Design}

In this survey, the design used was Crosssectional survey design. Cross-sectional design involves gathering of information by interrogating or administering questionnaire to a sample of population within a snapshot in that data can be gathered that can be a week, Month then analyzed. Cross-sectional design was preferred for the study due to its exploratory, explanatory and descriptive ability of social issues. The design was the most suitable for this research since it enabled the researcher to gather data through interrogating and administration of questionnaires that solicited the available information.

\section{Target Population}

Target population of the study was 290 that was representation of registered women groups in Rarieda Sub- County, of which general women group members were 190, 70purely Widows' groups, 20 Women group leaders and 10 Officers from the Ministry of Social services.

\section{Sample Size}

The total target population was 290. The sample size was determined by use of Krejcie and Morgan table of estimation of which this study had 165 respondents, Krejcie [24]. The table below shows how sample size was estimated from the target population.

urce: Krejcie and Morgan Table 


\section{Pilot Testing of Instruments}

The research instruments was pre-tested in Bondo Sub-County in Siaya County [25]. Advice that a researcher should try out the research instruments on a small sample of the population. A pilot study helps in testing the clarity and simplicity of the instruments. Check the specificity and contribution to the study. Bondo was chosen for piloting testing the instruments because it shares many characteristics with the geographical study area, Rarieda Sub -County. It has beaches and urban centers as Rarieda as culture is also the same in terms of language, socio-economically and by and large geographical similarities.

\section{Validity of Instruments}

Validity is the "accuracy and meaningfulness of inferences which are based on the research results. It is the degree to which results obtained from the analysis of data represent the phenomenon under study. Validity has to do with how accurately the data obtained in the study represents the variables of the study [26]".

\section{Reliability of Instruments}

According to Mugenda and Mugenda [26], reliability entails measure of degree of consistency of results or data that a survey tool yields after several trials. In this study reliability level will be brought to fore through piloting. The research instruments will be pre- pre-tested in Bondo Sub- County in Siaya County. Pilot testing allows a researcher to identify issues that may arise from the research instruments, be they ambiguity, complexity, indirect, ability to contribute to the study, whether the questions asked are focused to the variables or not, Kombo and Tromp [25]. Pretesting enables the researcher to learn how much time it takes to administer a questionnaire of interview schedule. The researcher will therefore use test the instrument with $10 \%$ of the sample

\section{Data Collection Procedure}

The researcher obtained a letter from University of Nairobi clearing the researcher to get a research permit. With the clearance letter from the University, an application was made for a permit from the "National Commission for Science, Technology and Innovation (NACOSTI)". Receipt of research permit allowed the researcher seek the approval from County Commissioner and the Department of Social Services and Gender at the County about the intention to carry out the research. The County Government was informed about the intention of the study.

\section{Ethical Consideration}

All research studies must take into account the aspect of ethical consideration to ensure that there is protection of not just the researcher's interest alone but also that of the information given by the participants in the study. According to Kombo and Tromp [25], an informed consent must be obtained from all participants, confidentiality must be maintained at all times, there must be reasonable protection of the subjects from any physical and psychological exposure and sharing the research in advance and debrief the subjects afterwards to help them understand the results and its effects on them. In this regard, the researcher in this study ensured the above was put into consideration.

\section{Questionnaire Return Rate}

The sample size for this study was 165 , out of the questionnaires sent out, 161 were completed and brought back. The return rate was thus $97.6 \%$. Table-2 summarizes the rate of questionnaire return.

\section{Demographic Characteristics of Respondents}

The study sought information on research participants' information. Table-3 presents personal information of the research participants.

Table-2: Distribution of Demographic Characteristics of Respondents Demographic descriptive

\begin{tabular}{|r|r|r|r|}
\hline \multicolumn{1}{|c|}{ Gender } & & Frequency & Percentage \\
\hline & Male & 15 & $9.3 \%$ \\
\cline { 2 - 4 } & Female & 146 & $90.7 \%$ \\
\hline \multirow{4}{*}{ Participant age } & Total & $\mathbf{1 6 1}$ & $\mathbf{1 0 0 . 0 \%}$ \\
\cline { 2 - 4 } & 16 to 20 & 8 & $5.0 \%$ \\
\cline { 2 - 4 } & 21 to 25 & 6 & $3.7 \%$ \\
\cline { 2 - 4 } & 26 to 30 & 14 & $8.7 \%$ \\
\cline { 2 - 4 } & 31 to 35 & 24 & $14.9 \%$ \\
\cline { 2 - 4 } & 36 to 40 & 29 & $18.0 \%$ \\
\cline { 2 - 4 } & 41 to 45 & 37 & $23.0 \%$ \\
\cline { 2 - 4 } & 46 to 50 & 26 & $16.1 \%$ \\
\cline { 2 - 4 } & Above 50 & 17 & $10.6 \%$ \\
\hline Education level & Total & $\mathbf{1 6 1}$ & $\mathbf{1 0 0 . 0 \%}$ \\
\cline { 2 - 4 } & PhD & 2 & $1.2 \%$ \\
\cline { 2 - 4 } & Masters' Degree & 0 & $0.0 \%$ \\
\cline { 2 - 4 } & Bachelors' Degree & 9 & $5.6 \%$ \\
\cline { 2 - 4 } & Diploma & 23 & $14.3 \%$ \\
\cline { 2 - 4 } & Secondary & 34 & $21.1 \%$ \\
\cline { 2 - 4 } & Primary & 81 & $50.3 \%$ \\
\hline
\end{tabular}




\begin{tabular}{|r|r|r|r|}
\hline & None & 12 & $7.5 \%$ \\
\cline { 2 - 4 } & Total & $\mathbf{1 6 1}$ & $\mathbf{1 0 0 . 0 \%}$ \\
\hline Marital status & Married & 69 & $42.9 \%$ \\
\cline { 2 - 4 } & Widowed & 76 & $47.2 \%$ \\
\cline { 2 - 4 } & Divorced & 11 & $6.8 \%$ \\
\cline { 2 - 4 } & Not Married & 5 & $3.1 \%$ \\
\cline { 2 - 4 } & Total & $\mathbf{1 6 1}$ & $\mathbf{1 0 0 . 0 \%}$ \\
\cline { 2 - 4 } Position in project & Social welfare officer & 8 & $5.0 \%$ \\
\cline { 2 - 4 } & Women Group leader & 32 & $19.9 \%$ \\
\cline { 2 - 4 } & Women Group Member & 121 & $75.2 \%$ \\
\hline & Total & $\mathbf{1 6 1}$ & $\mathbf{1 0 0 . 0 \%}$ \\
\hline
\end{tabular}

Table-2 presents the spread of demographic characteristics of research participants. The demographic questionnaire for project empowerment strategies and resilience of widows sought information on gender, age bracket, marital status, highest education qualification and position held in the groups of the respondents. Out of the 161 respondents, 146(90.7\%) were female and $15(9.3 \%)$ were male suggesting that most empowerment groups had women as members hence quite a high rate of women empowerment.

On the age bracket findings, respondents between age 41-45 years were the majority at 37(23\%), aged between $36-50$ years; $29(18.0 \%)$, aged between 46-50 years; 26(16.1\%), aged between 31-35 years were $24(14.9 \%)$, aged above 50 years; $17(10.6 \%)$, aged between 26-30 years; 14(8.7\%), aged between 1620year; $8(5.0 \%)$ and aged between $21-25$ were $6(3.7 \%)$.

Findings on highest educational qualification indicated that $81(50.3 \%)$ were primary school leavers, $34(21.1 \%)$ went up to secondary, $23(14.3 \%)$ were diploma holders, $12(7.5 \%)$ had no formal literacy skills, 9(5.6\%) were degree holders while $2(1.2 \%)$ were $\mathrm{PhD}$ holders. Suggesting that a good number of the SubCounty residents had literacy skills at least beyond reading and writing. However, it is also important to note that there still exist those who have no literacy skill at all.

The findings on marital status suggested that out of 161 respondents, 76(47.2\%) were widows, $69(42.9 \%)$ were married, $11(6.8 \%)$ were divorced while $5(3.1 \%)$ were not married. This indicates that widowhood was at a high rate that as compared to other marital statuses.

Lastly on demographic characteristics, findings revealed that out of the 161 respondents, $121(75.2 \%)$ were women group members, 32(19.9\%) were group leaders while $8(5.0 \%)$ were Social Welfare Officers. Empowerment Group membership is seen to be to a large extent in the sub-county an indication of involvement in empowerment activities.

\section{Descriptive Analysis of Resilience of Widows}

The study also sought information on the research respondents' perspectives on Resilience of Widows. The theoretical and empirical review of literature indicated that determination, independence, motivation, adaptability and innovativeness are important indicators of resilience. To measure resilience of widows, five statements on the indicators were developed in the self -administered questionnaire using a Likert scale.

Table-3: Descriptive Statistics on Resilience of Widows

\begin{tabular}{|c|c|r|r|r|r|r|r|r|}
\hline $\begin{array}{c}\text { Statements on Resilience } \\
\text { of Widows }\end{array}$ & $\begin{array}{r}\text { Strongly } \\
\text { Disagree }\end{array}$ & Disagree & Neutral & Agree & $\begin{array}{r}\text { Strongly } \\
\text { Agree }\end{array}$ & Total & $\begin{array}{r}\text { Mean } \\
\begin{array}{r}\text { Std. } \\
\text { Dev. }\end{array}\end{array}$ \\
\hline $\begin{array}{c}\text { Resilient Widows are } \\
\text { Determined (RWW - 1) }\end{array}$ & $0(0.0 \%)$ & $1(0.6 \%)$ & $16(9.9)$ & $30(18.6 \%)$ & $114(70.8 \%)$ & $161(100 \%)$ & 4.60 & 0.693 \\
\hline $\begin{array}{c}\text { Resilient Widows are } \\
\text { Independent (RWW - 2) }\end{array}$ & $1(0.6 \%)$ & $5(3.1 \%)$ & $20(12.4 \%)$ & $55(34.2 \%)$ & $80(49.7 \%)$ & $161(100 \%)$ & 4.29 & 0.849 \\
\hline $\begin{array}{c}\text { Resilient Widows are } \\
\text { Motivated (RWW - 3) }\end{array}$ & $1(0.6 \%)$ & $5(3.1 \%)$ & $25(15.5 \%)$ & $38(23.6 \%)$ & $92(57.1 \%)$ & $161(100 \%)$ & 4.34 & 0.894 \\
\hline $\begin{array}{c}\text { Resilient Widows are } \\
\text { Adaptable (RWW - 4) }\end{array}$ & $4(2.5 \%)$ & $8(5.0 \%)$ & $31(19.3 \%)$ & $42(26.1 \%)$ & $76(47.2 \%)$ & $161(100 \%)$ & 4.11 & 1.040 \\
\hline $\begin{array}{c}\text { Resilient Widows are } \\
\text { Innovative (RWW - 5) }\end{array}$ & $9(5.6 \%)$ & $15(9.3 \%)$ & $21(13.0 \%)$ & $26(16.1 \%)$ & $90(55.9 \%)$ & $161(100 \%)$ & 4.07 & 1.253 \\
\hline
\end{tabular}

Table-3 presents the descriptive statistics on resilience of Widows. Item RWW-1 sought to establish the level of determination in resilient widows. Out of 161 research participants who gave their views on the statement, $114(70.8 \%)$ had stronger agreement, $30(18.6 \%)$ said yes, $16((9.9 \%)$ were neutral, $1(0.6 \%)$ disagreed while none had strong disagreement for the item. The Mean of the statement RWW-1 was 4.60 with the standard deviation being 0.693 , suggesting that most of the research participants agreed that resilient widows are determined. 
Item RWW-2 sought to establish the types of independence in resilient widows. Out of 161 respondents who responded to the item, 80(49.7\%) strongly agreed, 55(34.2\%) agreed, 20(12.4\%) were neutral, $5(3.1 \%)$ disagreed while $1(0.6 \%)$ strongly rejected the item. The mean was 4.26 and the standard deviation was 0.849 , indicating majority of research participants gave a nod to the item resilient widows are independent.

Item RWW-3 sought to establish the nature of motivation in resilient widows. Out of 161 interviewees who responded to the statement, $92(57.1 \%)$ gave strong acceptance, 38(23.6\%) agreed, 25(15.5\%) were neutral, $5(3.1 \%)$ rejected and $1(0.6 \%)$ strongly disallowed. Its mean came to 4.34 and the standard deviation stood at 0.894 , pointing to the fact that most interviewees passed the statement that resilient widows are enthusiastic.

Item RWW-4 Undertook to find out nature of adaptability in resilient widows. Out of $16176(47.2 \%)$ had strong acceptance, 42(26.1\%) agreed, 31(19.3\%) were neutral, $8(5.0 \%)$ disagreed while $4(2.5 \%)$ strongly disagreed. The mean was 4.11 and the standard deviation was 1.040 indicating that most of the research participants agreement with the statement that, resilient widows are adaptable.

Item RWW-5 sought to establish ways in which resilient widows were innovative. Out of the 161 respondents, 90(55.9\%) strongly agreed, 26(16.1\%) agreed, 21(13.0\%) were neutral, 15(9.3\%) disagreed and $9(5.6 \%)$ strongly disagreed. The mean for item 5 was 4.07 and the standard deviation was 1.253 a pointer that a good number of respondents agreed that resilient widows are innovative.

\section{Descriptive Analysis of Project Advocacy Strategy}

The study sought to establish the frequencies, percentages, averages, and deviation on project advocacy strategy.

Table-4: Descriptive Statistics on Project Advocacy Strategy

\begin{tabular}{|r|r|r|r|r|r|r|r|r|}
\hline Statements & $\begin{array}{r}\text { Strongly } \\
\text { Disagree }\end{array}$ & Disagree & Neutral & Agree & $\begin{array}{r}\text { Strongly } \\
\text { Agree }\end{array}$ & Total & Mean & $\begin{array}{r}\text { Std. } \\
\text { Deviation }\end{array}$ \\
\hline $\begin{array}{l}\text { Women Empowerment } \\
\text { Projects defend widows } \\
\text { (PAS - 1) }\end{array}$ & $1(0.6 \%)$ & $5(3.1 \%)$ & $25(15.5 \%)$ & $56(34.8 \%)$ & $74(46.0 \%)$ & $161(100 \%)$ & 4.22 & 0.866 \\
\hline $\begin{array}{c}\text { Women Empowerment } \\
\text { Projects provide support } \\
\text { to widows (PAS - 2) }\end{array}$ & $2(1.2 \%)$ & $3(1.9 \%)$ & $20(12.4 \%)$ & $47(29.2 \%)$ & $89(55.3 \%)$ & $161(100 \%)$ & 4.35 & 0.862 \\
\hline $\begin{array}{l}\text { Women Empowerment } \\
\text { Projects champion the } \\
\text { rights of widows (PAS - }\end{array}$ & $19(0.6 \%)$ & $10(6.2 \%)$ & $29(18.0 \%)$ & $59(36.6 \%)$ & $62(38.5 \%)$ & $161(100 \%)$ & 4.06 & 0.933 \\
\hline $\begin{array}{l}\text { Women Empowerment } \\
\text { Projects endorse issues of } \\
\text { widows (PAS - 4) }\end{array}$ & 0 & $16(9.9 \%)$ & $33(20.5 \%)$ & $41(25.5 \%)$ & $71(44.1)$ & $161(100 \%)$ & 4.04 & 1.024 \\
\hline $\begin{array}{l}\text { Women Empowerment } \\
\text { Projects promote widows } \\
\text { agenda (PAS - 5) }\end{array}$ & $1(0.6 \%)$ & $17(10.6 \%)$ & $25(15.5 \%)$ & $36(22.4 \%)$ & $82(50.9 \%)$ & $161(100 \%)$ & 4.12 & 1.065 \\
\hline
\end{tabular}

Table-4 presents the descriptive statistics on project advocacy strategy. Statement on PAS-1 undertook to establish to what extent women empowerment projects defend the widows. Out of 161repondents who responded to this, 74(46.0\%) strongly agreed, 56(34.8\%) were in agreement, $25(15.5 \%)$ were split in the middle, $5(3.1 \%)$ disallowed while $1(0.6 \%)$ marked strong disagreement for the item. Its average was 4.22 while the standard deviation was 0.866, suggesting that high numbers of those interviewed strongly agreed with this statement.

Item PAS-2 sought to establish the nature of support women empowerment projects give widows. Of 161 participants, $89(55.3 \%)$ gave strong nod, $47(29.2 \%)$ agreed, 20(12.4\%) had balanced feelings, 3(1.9\%) disallowed and $2(1.2 \%)$ had strong rejection for the item. The mean for the item was 4.35 and the standard deviation was 0.862 , indicating that majority respondents agreed empowerment projects provide support to widows.

Item PAS-3 sought to establish that women empowerment projects champion the rights of widows. Out of 161 respondents that responded to the item, $62(38.5 \%)$ strongly agreed, 59(36.6\%) a nod, $29(18.0 \%)$ had split agreement, $10(6.2 \%)$ rejected, $1(0.6 \%)$ strongly rejected the statement. Average for the item came to 4.06 and the standard deviation was 0.933 indicating that record number of respondents agreed with statement.

Item PAS-4 sought to examine the method in which women empowerment projects endorse the issues of widows. Out of 161 research participants that participated in answering the item $71(44.1 \%)$ in strong agreement, $41(25.5 \%)$ gave a nod, $33(20.5 \%)$ were neutral, $16(9.9 \%)$ disagreed and none had strong disagreement. The average for the item stood at 4.04 
and the standard deviation was 1.024, signifying a good number of research participants were in agreement with the item.

Item PAS-5 sought to establish means by which women empowerment projects promote widows' agenda. Out of the 161 respondents $82(50.9 \%)$ strongly agreed, 36(22.4\%) agreed, 25(15.5\%) were neutral, $17(10.6 \%)$ disagreed while $1(0.6 \%)$ strongly disagreed with the statement. The mean for the item was 4.12 and the standard deviation was 1.065 , a pointer that majority agreed with statement, women empowerment projects promote widows' agenda.

\section{Inferential Analysis}

Correlation and regression analyses were carried out to establish the association between project advocacy strategy and resilience of widows.

\section{Correlation analysis of Project Advocacy Strategy and resilience of widows}

Pearson product moment correlation coefficient was applied to establish the presence or non -existence of significant relationship along with strength of association between project advocacy strategy and resilience of widows, based on the respondents' standpoints.

Table-5: Correlation Statistics

\begin{tabular}{|r|r|r|r|}
\hline \multicolumn{9}{|c|}{ Correlations } \\
\hline \multirow{2}{*}{ Project Advocacy Strategy } & Project Advocacy Strategy & Dependent Variable. Resilience of widows \\
\cline { 2 - 5 } & Pearson Correlation & 1 & $0.584^{* *}$ \\
\cline { 2 - 5 } & Sig. (2-tailed) & 161 & 0.000 \\
\hline Resilience of Widows & Pearson Correlation & $0.584^{* *}$ & 161 \\
\cline { 2 - 5 } & Sig. (2-tailed) & 0.000 & 1 \\
\cline { 2 - 5 } & \multicolumn{7}{|c|}{$* *$ Correlation is significant at the 0.01 level (2-tailed). } & 161 \\
\hline
\end{tabular}

Table-5 represents correlations statistics on project advocacy Strategy and resilience of widows. The analysis shows an averagely strong correlation between Project Advocacy strategy and resilience of widows with $\mathrm{r}=0.584 \mathrm{P}<0.01)$. Results indicated presence of statistical significance concerning project advocacy strategy and resilience of widows.

\section{Regression Analysis}

To find the amount of variation in resilience of widows which explains its association with project advocacy strategy, the coefficient of determination $\left(\mathrm{R}^{2}\right)$ was worked out. The coefficient was also computed to help in understanding or explaining the variation in resilience of widows.

Table-6: A model Summary

\begin{tabular}{|r|r|r|r|r|r|r|r|r|r|}
\hline Model & $\mathbf{R}$ & $\begin{array}{r}\text { R } \\
\text { Square }\end{array}$ & $\begin{array}{r}\text { Adjusted R } \\
\text { Square }\end{array}$ & $\begin{array}{r}\text { Std. Error of the } \\
\text { Estimate }\end{array}$ & $\begin{array}{r}\text { R Square } \\
\text { Change }\end{array}$ & $\begin{array}{r}\text { F } \\
\text { Change }\end{array}$ & df1 & df2 & $\begin{array}{r}\text { Sig. F } \\
\text { Change }\end{array}$ \\
\hline 1 & $0.584^{\mathrm{a}}$ & 0.342 & \multicolumn{8}{|c|}{ a. Predictors: (Constant), Project Advocacy Strategy } & 0.000 \\
\hline
\end{tabular}

Table-6 is the model summary of the relationship between Project Advocacy Strategy and resilience of widows. The above model summary table indicates presence of a positive multiple correlation coefficient $(\mathrm{R}=0.584)$ between resilience of widows and
Project advocacy strategy and those projected by regression model. Again, the coefficient of determination $\left(\mathrm{R}^{2}=34.2 \%\right)$ indicates that variance in resilience of widows is also defined by project advocacy strategy.

Table-7: Analysis of Variance

\begin{tabular}{|c|c|c|c|c|c|c|}
\hline \multicolumn{7}{|c|}{ ANOVA } \\
\hline & Model & Sum of Squares & $\mathrm{df}$ & Mean Square & $\mathrm{F}$ & Sig. \\
\hline \multirow[t]{3}{*}{1} & Regression & 35.065 & 1 & 35.065 & 82.468 & $.000^{\mathrm{b}}$ \\
\hline & Residual & 67.606 & 159 & .425 & & \\
\hline & Total & 102.670 & 160 & & & \\
\hline \multicolumn{7}{|c|}{ a. Dependent Variable: Resilience of widows } \\
\hline & & b. Predictors: & Cons & ant), Project Ac & vocacy $\mathrm{S}$ & categy \\
\hline
\end{tabular}

Table-8 ANOVA significance of relationship between independent variables or $\mathrm{p}$ value stands at 0.000 that is less than 0.05 . This compels the result to reject the null hypotheses that; "There is no significant relationship between project Advocacy strategy and Resilience of Widows". 
Table-8: Regression Coefficients

\begin{tabular}{|c|c|c|c|c|c|c|}
\hline \multirow{2}{*}{\multicolumn{2}{|c|}{ Model }} & \multicolumn{2}{|c|}{ Unstandardized Coefficients } & \multirow{2}{*}{$\begin{array}{r}\text { Standardized Coefficients } \\
\text { Beta }\end{array}$} & \multirow[t]{2}{*}{$\mathbf{t}$} & \multirow[t]{2}{*}{ Sig. } \\
\hline & & $\mathbf{B}$ & Std. Error & & & \\
\hline \multirow[t]{2}{*}{1} & (Constant) & 1.892 & .268 & & 7.061 & .000 \\
\hline & Project Advocacy Strategy & .574 & .063 & .584 & 9.081 & .000 \\
\hline
\end{tabular}

From the results the analyses return $b$ coefficient constant of 1.892 and predictive variable of 0.574 . This means that a 1-point increase on the independent variable corresponds to 0.574 points increase on the dependent variable. Furthermore, all the coefficients of 0.000 , which is less than 0.05 , indicating that all the $b$ coefficients are statistically significant.

\section{DISCUSSION}

The study examined the effect of project advocacy strategy and resilience of widows. The analysis shows a strong correlation between project advocacy strategy and resilience of widows by $(r=0.584$ $\mathrm{p}<0.01)$. Designating presence of statistical significance between the two variables. The coefficient of determination $0.58(5.84 \%)$ suggests that project advocacy strategy accounted for only $5.84 \%$ of Resilience of widows while the remaining $94.16 \%$ could be as a result of other factors. This research was delimitated to project advocacy strategy and resilience of widows. Based on these findings, research should be conducted to assess the influence of faith, religion and formal education level on resilience of widows. Further research should also be conducted on project empowerment strategies in the whole County, since the research was delimited just to widows in Rarieda SubCounty. Further research should also be done on influence of social support systems like family around individual widows and age effects on the widows.

\section{REFERENCES}

1. Hartmann, D., \& Kwauk, C. (2011). Sport and development: An overview, critique, and reconstruction. Journal of sport and social issues, 35(3), 284-305.

2. Folke, C. C. (2010). Resilience Thinking Integrating Resilience, Adaptability and Transformability. Ecology and Society, 15(4), 39.

3. Parker, S. L., Jimmieson, N. L., Walsh, A. J., \& Loakes, J. (2015). Trait Resilience Fosters Adaptive Coping When Control Opportunities are High:Implications for the Motivating Potential of Active Work. Journal of Business and Psychology, 583-604.

4. Dwivedi, R. S. (1998). Theoretical Perspectives and Applications in Indian Organisations. Indian Journal of Industrial Relations, 164-182.

5. Mynttinen, E., Wester, N., Lilius, T., Kalso, E., Koskinen, J., \& Laurila, T. (2019). Simultaneous electrochemical detection of tramadol and Odesmethyltramadol with Nafion-coated tetrahedral amorphous carbon electrode. Electrochimica Acta, 295, 347-353.

6. Kaplan, H. B., \& Pokorny, A. D. (1969). Selfderogation and psychosocial adjustment. Journal of nervous and Mental Disease.

7. Chopra, D., Ekeoba, P., Nesbitt-Ahmed, Z., Moussié, R., \& Sherpa, M. (2014). Policy advocacy for women's unpaid care work: comparing approaches and strategies in Nepal and Nigeria. Gender and Development, 22(3), 475494.

8. Brahic, B., Olaiya, M. M., Jacobs, S., \& English, R. (2011). Organizing Women Workers in the Agribusiness Sector: Case Studies from East Africa. Labour, Capital and Society, 44(1), 7097.

9. Cherif, F. M. (2010). Culture, Rights, and Norms: Women's Rights Reform in Muslim Countries. Journal of Politics, 72(4), 1144-1160.

10. McGovern, T. (2013). No risk, no gain: invest in women and girls by funding advocacy, organizing, litigation and work to shift culture. Reproductive Health Matters, 21(42), 86-102.

11. McGovern, D. P., Gardet, A., Törkvist, L., Goyette, P., Essers, J., Taylor, K. D., ... \& Green, T. (2010). Genome-wide association identifies multiple ulcerative colitis susceptibility loci. Nature genetics, 42(4), 332.

12. Olsen, A. M. S., Fosb $\varnothing 1$, E. L., Lindhardsen, J., Folke, F., Charlot, M., Selmer, C., ... \& Hansen, P. R. (2012). Long-term cardiovascular risk of nonsteroidal anti-inflammatory drug use according to time passed after first-time myocardial infarction: a nationwide cohort study. Circulation, 126(16), 1955-1963.

13. Parker, T. J., Berry, G. J., Reeder, M. J., \& Nicholls, N. (2014). Modes of climate variability and heat waves in Victoria, southeastern Australia. Geophysical Research Letters, 41(19), 6926-6934.

14. Rappaport, A. (1981). Selecting strategies that create shareholder value. Harvard Business Review, 59(3).

15. Kaplan, C. P., Turner, S., Norman, E., \& Stillson, K. (1996). Promoting resilience strategies: A modified consultation model. Children \& Schools, 18(3), 158-168.

16. Comeau, G. S., \& Church, A. G. (2010). A Comparative Analysis of Women's Sport Advocacy Groups in Canada and the United States. Journal of Sport and Social Issues, 34(4), 457-474. 
17. Smyntyna, O. (2016). Cultural resilience theory as an instrument of modeling human response to global climate change. A case study in the northwestern black sea region on the PleistoceneHolocene boundary: Aplicación de la teoría de la resiliencia cultural como modelo de respuesta humana al cambio climático global. El caso de la región noroeste del mar negro entre Pleistoceno y Holoceno. Riparia, (2), 1.

18. Holling, C. S. (1973). Resilience and stability of ecological systems. Annual review of ecology and systematics, 4(1), 1-23.

19. Howell, K. H., Thurston, I. B., Schwartz, L. E., Jamison, L. E., \& Hasselle, A. J. (2018). Protective Factors associated with Resilience in Women Exposed to Intimate Partner Violence. Psychology of Violence, 8(4), 438-447.

20. Howlett, M., \& Migone, A. (2013). Searching for substance: externalization, politicization and the work of canadian policy consultants 20062013. Central European Journal of Public Policy, 7(1).
21. Hirani, S. S., Norris, C. M., Van Vliet, K. J., Van Zanten, S. V., Karmaliani, R., \& Lasiuk, G. (2018). Social support intervention to promote resilience and quality of life in women living in Karachi, Pakistan: a randomized controlled trial. International Journal of Public Health, 63(6), 693-702.

22. Polk, L. V. (1997). Toward a middle-range theory of resilience. Advances in nursing science, 19(3), $1-13$.

23. Dale, S. K., \& Safren, S. A. (2019). Resilience takes a village: black women utilize support from their community to foster resilience against multiple adversities. AIDS Care, 1-9.

24. Krejcie, R. (1970). Determining Sample Size for Research Activities. Educational and Psychological Measurement, 607-610

25. Kombo, K. D., \& Tromp, A. D. (2011). Proposal and thesis writing: An introduction. Nairobi: Pauline Publications Africa.

26. Mugenda, O. M., \& Mugenda, A. G. (2003). Research Methods.Quantitative and qualitative Approaches. Nairobi: Acts press. 